\title{
Pseudomonas xinjiangensis sp. nov., a moderately thermotolerant bacterium isolated from desert sand
}

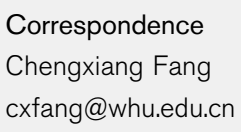

\author{
Ming Liu, Xuesong Luo, Lei Zhang, Jun Dai, Yang Wang, Yali Tang, \\ Jing Li, Tongjun Sun and Chengxiang Fang \\ College of Life Sciences, Wuhan University, Wuhan 430072, PR China
}

Pseudomonas species are important members of natural microbial communities. The genus was first created by Migula (1894) and, at the time of writing, 181 species with validly published names have been described (http:// www.bacterio.cict.fr/p/pseudomonas.html). Most species in the genus Pseudomonas are motile by one or several polar flagella, fail to grow under acid conditions, contain $\mathrm{C}_{10: 0} 3-\mathrm{OH}, \mathrm{C}_{12: 0}$ and $\mathrm{C}_{12: 0} 2-\mathrm{OH}$ as major fatty acids and do not accumulate polyhydroxybutyrate granules (Palleroni, 2005). Pseudomonas species have been isolated from diverse environments such as soils, plants, fresh water, clinical specimens and marine environments (Palleroni, 1992; Romanenko et al., 2005). However, few species have been recovered from dry environments; the characteristics of pseudomonads isolated from deserts have not been reported.

In the present study, strain $\mathrm{S} 3-3^{\mathrm{T}}$ was isolated from a sand sample from a desert in Xinjiang province, China, using tenfold-diluted tryptic soy broth (TSB/10; Difco) agar. After 1 week of incubation at $30{ }^{\circ} \mathrm{C}$, colonies were yellow, circular and convex $(<1 \mathrm{~mm}$ in diameter) with entire edges. Cell morphology was examined by light microscopy and electron microscopy. Motility was observed by using motility agar. Cells were rod-shaped and motile. The strain

Abbreviation: $\mathrm{PHB}$, poly- $\beta$-hydroxybutyrate.

The GenBank/EMBL/DDBJ accession number for the 16S rRNA gene sequence of strain $\mathrm{S} 3-3^{\mathrm{T}}$ is EU286805. could grow on marine agar 2216 (MA; Difco) and R2A agar (Difco).

Genomic DNA for amplification of the 16S rRNA gene was extracted with a Bacteria Genomic DNA Isolation kit (Shanghai Chaoshi Bio Technologies). The 16S rRNA gene was amplified by PCR with bacterial universal primers $27 \mathrm{~F}$ and 1492R (Lane, 1991) and the PCR products were sequenced by Invitrogen Biotechnology Co. Ltd. Similarity searches with the derived sequences were done by BLAST at NCBI (http://www.ncbi.nlm.nih.gov/). Phylogenetic analysis was performed by using MEGA version 3.1 (Kumar et al., 2004) after multiple alignment of the data via ClustaL_X (Thompson et al., 1997). Distances were obtained using options according to Kimura's twoparameter model (Kimura, 1980) and clustering was performed by using the neighbour-joining method (Saitou \& Nei, 1987) and maximum-parsimony method (MEGA 3.1; data not shown). The topology of the neighbour-joining phylogenetic tree was evaluated by using bootstrap resampling (Felsenstein, 1985) with 1000 replications (Fig. 1).

The 16S rRNA gene sequence of strain $\mathrm{S} 3-3^{\mathrm{T}}$ showed the highest similarity to those of Pseudomonas plecoglossicida FPC $951^{\mathrm{T}}(96.23 \%)$, followed by Pseudomonas pachastrellae KMM $330^{\mathrm{T}}(96.16 \%)$, Pseudomonas mosselii CIP $105259^{\mathrm{T}}$ (GenBank accession no. AF072688, not shown in Fig. 1; $96.16 \%)$ and Pseudomonas monteilii CIP $104883^{\mathrm{T}}$ (AF064458, not shown in Fig. 1; 96.06\%), and showed 


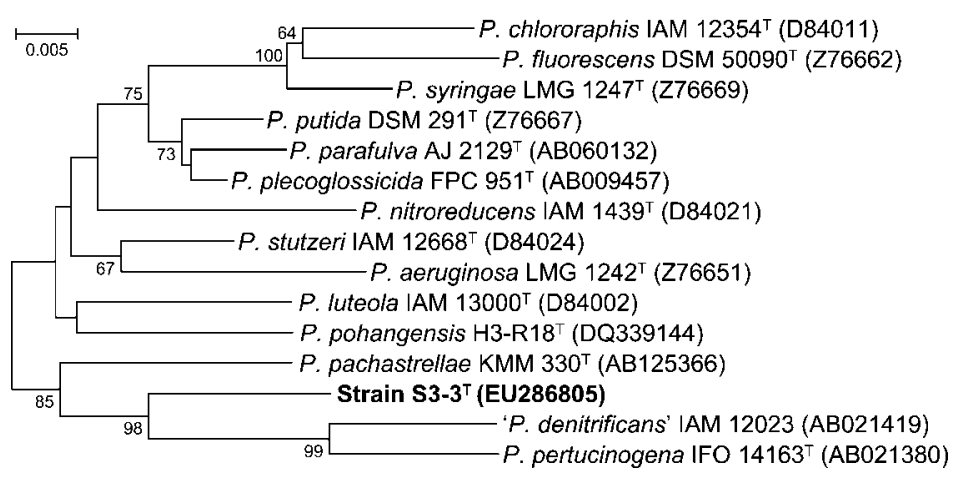

Fig. 1. Neighbour-joining tree based on $16 \mathrm{~S}$ rRNA gene sequences, showing the phylogenetic relationship between strain $\mathrm{S} 3-3^{\top}$ and other species of the genus Pseudomonas. Bootstrap values (expressed as percentages of 1000 replications) greater than $50 \%$ are given at nodes. Bar, $0.5 \%$ sequence difference.

less than $96 \%$ sequence similarity to other species of the genus Pseudomonas. A global phylogenetic analysis indicates that the strain cannot be affiliated to any of the intrageneric groups (the $P$. syringae, $P$. chlororaphis, $P$. fluorescens, P. putida, P. stutzeri, $P$. aeruginosa and $P$. pertucinogena groups) proposed by Anzai et al. (2000) within Pseudomonas sensu stricto (data not shown), forming a distinct branch between $P$. pachastrellae and the $P$. pertucinogena group. The sequences from its close neighbours and representative species (Pseudomonas syringae, P. chlororaphis, P. fluorescens, P. putida, P. stutzeri, P. aeruginosa and $P$. pertucinogena) from each of the Pseudomonas intrageneric groups were selected to build the phylogenetic tree (Fig. 1).

Fatty acid methyl esters were analysed by using the Sherlock Microbial Identification System (MIDI) according to the manufacturer's instructions (MIDI, 2005) after $48 \mathrm{~h}$ incubation on TSB agar at $30{ }^{\circ} \mathrm{C}$. The strain included summed feature $8\left(\mathrm{C}_{18: 1} \omega 6 c\right.$ and/or $\left.\mathrm{C}_{18: 1} \omega 7 c\right)(24.48 \%)$, summed feature $3\left(\mathrm{C}_{16: 1} \omega 7 c\right.$ and/or iso- $\left.\mathrm{C}_{15: 0} 2-\mathrm{OH}\right)$ (19.70\%), $\mathrm{C}_{19: 0}$ cyclo $\omega 8 c(10.78 \%), \mathrm{C}_{17: 0}$ cyclo $(7.54 \%)$, $\mathrm{C}_{16: 0}(6.58 \%), \mathrm{C}_{12: 0}(5.57 \%)$ and $\mathrm{C}_{13: 0} 3-\mathrm{OH}(4.45 \%)$ as major fatty acids. The respiratory quinone system was extracted and determined by HPLC as described by Xie \& Yokota (2003). Analysis of respiratory lipoquinones indicated that the isolate contained ubiquinone-9 (Q-9), corresponding to the characteristic feature of members of the genus Pseudomonas (Oyaizu \& Komagata, 1983). The DNA $\mathrm{G}+\mathrm{C}$ content of strain $\mathrm{S} 3-3^{\mathrm{T}}$, determined using an HPLC method (Mesbah et al., 1989), was 60.9 mol\%.

To investigate the physiological and biochemical characteristics of strain $\mathrm{S} 3-3^{\mathrm{T}}$ further, we used the methods described by Palleroni \& Doudoroff (1972) and Smibert \& Krieg (1994) for the following tests: Gram reaction, oxidase and catalase reactions, accumulation of poly- $\beta$-hydroxybutyrate (PHB), arginine dihydrolase, nitrate reduction and hydrolysis of gelatin, starch, casein and Tween 80 . Production of pyocyanin and formation of fluorescent pigments were tested on King A and King B medium, respectively (King et al., 1954). Temperature tolerance was tested by checking growth at $4,12,21,30,37,42$ and $45^{\circ} \mathrm{C}$ and tolerance of salinity was tested with growth on TSB agar with $1,3,5,7,9,10$ and $11 \%(\mathrm{w} / \mathrm{v}) \mathrm{NaCl}$. The $\mathrm{pH}$ range ( $\mathrm{pH} 4-10$ at intervals of $1 \mathrm{pH}$ unit) for growth was determined in marine broth (Difco). In addition, the API 20NE, API ZYM systems (bioMérieux) and Biolog GN2 MicroPlates (Biolog) were used to test biochemical properties and these tests were performed according to the manufacturers' instructions. The physiological and biochemical characteristics of strain $\mathrm{S} 3-3^{\mathrm{T}}$ are listed in the species description and in Table 1.

Strain $\mathrm{S} 3-3^{\mathrm{T}}$ showed characteristics similar to those of $P$. pachastrellae in their lack of carbohydrate utilization. However, strain S3-3 ${ }^{\mathrm{T}}$, P. plecoglossicida and $P$. pachastrellae utilize different carbohydrates. Strain $\mathrm{S} 3-3^{\mathrm{T}}$ can be distinguished from $P$. pertucinogena based on the presence of intracellular pigment, accumulation of PHB and hydrolysis of Tween 80 (Table 1).

Organisms sharing 16S rRNA gene sequence similarity of less than $97 \%$ are usually regarded as belonging to different bacterial species (Stackebrandt \& Goebel, 1994). Thus, from the phylogenetic analysis and the physiological tests, it is evident that strain $\mathrm{S} 3-3^{\mathrm{T}}$ represents a distinct, previously undescribed species within the genus Pseudomonas. In conclusion, strain $\mathrm{S} 3-3^{\mathrm{T}}$ is phylogenetically and physiologically distinct and represents a novel species, for which we propose the name Pseudomonas xinjiangensis sp. nov.

\section{Description of Pseudomonas xinjiangensis sp. nov.}

Pseudomonas xinjiangensis (xin.jiang.en'sis. N.L. fem. adj. xinjiangensis pertaining to Xinjiang, in north-west China, where the type strain was isolated).

Cells are Gram-negative, motile, non-spore-forming rods, 0.9-1.8 $\times 0.6-0.7 \mu \mathrm{m}$. Colonies are yellow. Pyocyanin on King A medium and fluorescent pigments on King B medium are not produced. Catalase- and oxidase-positive. Growth occurs at $4-42{ }^{\circ} \mathrm{C}$ (optimum $37{ }^{\circ} \mathrm{C}$ ), pH 6-9 (optimum $\mathrm{pH} 8$ ) and at $\mathrm{NaCl}$ concentrations of up to $6 \%$ (optimum 1-3\%). Does not hydrolyse gelatin, casein or starch. Hydrolysis of Tween 80 is positive. Shows positive reactions for nitrate reduction, but negative reactions for aesculin hydrolysis, gelatin hydrolysis, indole production, glucose fermentation and arginine dihydrolase, urease and 
Table 1. Differential phenotypic characteristics of strain S3-3 ${ }^{\top}$ and related Pseudomonas species

Taxa: 1, strain $\mathrm{S} 3-3^{\mathrm{T}} ; 2$, P. pachastrellae $\mathrm{KMM} 330^{\mathrm{T}} ; 3, \quad P$. plecoglossicida ATCC $700383^{\mathrm{T}}$; 4, P. pertucinogena (data from Kawai \& Yabuuchi, 1975). +, Positive; -, negative; ND, no data available. Data are from this study unless otherwise indicated.

\begin{tabular}{|c|c|c|c|c|}
\hline Characteristic & 1 & 2 & 3 & 4 \\
\hline \multicolumn{5}{|l|}{ Production of: } \\
\hline Yellow/orange cellular pigment & + & - & - & - \\
\hline Fluorescent pigment & - & - & + & ND \\
\hline Urease & - & + & + & - \\
\hline PHB accumulation & + & + & + & - \\
\hline Arginine dihydrolase & - & - & + & - \\
\hline \multicolumn{5}{|l|}{ Growth at: } \\
\hline $4{ }^{\circ} \mathrm{C}$ & + & $--^{a_{\star}}$ & $-{ }^{b}$ & ND \\
\hline $41{ }^{\circ} \mathrm{C}$ & + & $+{ }^{a}$ & $-{ }^{b}$ & + \\
\hline Tolerance of $8 \% \mathrm{NaCl}$ & - & $+{ }^{a}$ & $-{ }^{b}$ & ND \\
\hline \multicolumn{5}{|l|}{ Hydrolysis of: } \\
\hline Tween 80 & + & $+{ }^{a}$ & $-{ }^{b}$ & - \\
\hline Aesculin & - & + & + & ND \\
\hline \multicolumn{5}{|l|}{ Assimilation of: } \\
\hline D-Glucose & - & - & + & - \\
\hline Maltose & - & - & - & - \\
\hline D-Mannose & - & - & + & - \\
\hline D-Mannitol & - & - & - & - \\
\hline Gluconate & - & - & - & ND \\
\hline L-Arabinose & - & - & + & - \\
\hline Potassium gluconate & - & - & + & - \\
\hline Capric acid & - & + & + & ND \\
\hline Adipic acid & + & - & - & $\mathrm{ND}$ \\
\hline Malic acid & - & + & + & ND \\
\hline Trisodium citrate & - & + & + & ND \\
\hline Phenylacetic acid & - & - & + & $\mathrm{ND}$ \\
\hline
\end{tabular}

${ }^{*}$ Data taken from: $a$, Romanenko et al. (2005); b, Nishimori et al. (2000).

$\beta$-galactosidase activities. Assimilates adipic acid, but not D-glucose, L-arabinose, D-mannose, D-mannitol, $\mathrm{N}$-acetylglucosamine, capric acid, malic acid, maltose, potassium gluconate, trisodium citrate or phenylacetic acid. Positive for alkaline phosphatase, esterase (C4), esterase lipase (C8), lipase (C14), leucine arylamidase, acid phosphatase and naphthol-AS-BI-phosphohydrolase, but negative for valine arylamidase, cystine arylamidase, trypsin, $\alpha$-chymotrypsin, $\alpha$-galactosidase, $\beta$-galactosidase, $\beta$-glucuronidase, $\alpha$-glucosidase, $\beta$-glucosidase, $N$-acetyl- $\beta$-glucosaminidase, $\alpha$-mannosidase and $\alpha$-fucosidase. In Biolog GN2 plates, the type strain utilizes Tweens 40 and 80 , pyruvic acid methyl ester, cis-aconitic acid and $\alpha$-ketoglutaric acid. Major fatty acids are summed feature $8 \quad\left(\mathrm{C}_{18: 1} \omega 6 c\right.$ and/or $\left.\mathrm{C}_{18: 1} \omega 7 c\right)$, summed feature $3\left(\mathrm{C}_{16: 1} \omega 7 c\right.$ and/or iso- $\left.\mathrm{C}_{15: 0} 2-\mathrm{OH}\right)$, $\mathrm{C}_{19: 0}$ cyclo $\omega 8 c, \mathrm{C}_{17: 0}$ cyclo, $\mathrm{C}_{16: 0}, \mathrm{C}_{12: 0}$ and $\mathrm{C}_{13: 0} 3-\mathrm{OH}$. Ubiquinone Q-9 is the major respiratory quinone. The DNA G + C content of the type strain is $60.9 \mathrm{~mol} \%$.
The type strain is $\mathrm{S} 3-3^{\mathrm{T}}$ (=CCTCC AB $207151^{\mathrm{T}}=$ NRRL B$51270^{\mathrm{T}}$ ), isolated from desert sand in Xinjiang province, China.

\section{Acknowledgements}

This work was supported by the R\&D Infrastructure and Facility Development Program from the Ministry of Science and Technology of the People's Republic of China (Grant203 no. 2005DKA21208). We also thank Professor Tianshen Tao for help with references.

\section{References}

Anzai, Y., Kim, H., Park, J.-Y., Wakabayashi, H. \& Oyaizu, H. (2000). Phylogenetic affiliation of the pseudomonads based on 16S rRNA sequence. Int J Syst Evol Microbiol 50, 1563-1589.

Felsenstein, J. (1985). Confidence limits on phylogenies: an approach using the bootstrap. Evolution 39, 783-791.

Kawai, Y. \& Yabuuchi, E. (1975). Pseudomonas pertucinogena sp. nov., an organism previously misidentified as Bordetella pertussis. Int J Syst Bacteriol 25, 317-323.

Kimura, M. (1980). A simple method for estimating evolutionary rates of base substitutions through comparative studies of nucleotide sequences. J Mol Evol 16, 111-120.

King, E. O., Ward, M. K. \& Rainey, D. E. (1954). Two simple media for demonstration of pyocyanin and fluorescein. J Lab Clin Med 44, 301307.

Kumar, S., Tamura, K. \& Nei, M. (2004). MEGA3: integrated software for molecular evolutionary genetics analysis and sequence alignment. Brief Bioinform 5, 150-163.

Lane, D. J. (1991). 16S/23S rRNA sequencing. In Nucleic Acid Techniques in Bacterial Systematics, pp. 115-176. Edited by E. Stackebrandt \& M. Goodfellow. Chichester: Wiley.

Mesbah, M., Premachandran, U. \& Whitman, W. B. (1989). Precise measurement of the $\mathrm{G}+\mathrm{C}$ content of deoxyribonucleic acid by highperformance liquid chromatography. Int J Syst Bacteriol 39, 159-167.

MIDI (2005). Sherlock Microbial Identification System Operating Manual, version 6.0. Newark, DE: MIDI Inc.

Migula, W. (1894). Über ein neues System der Bakterien. Arb Bakteriol Inst Karlsruhe 1, 235-238 (in German).

Nishimori, E., Kita-Tsukamoto, K. \& Wakabayshi, H. (2000). Pseudomonas plecoglossicida sp. nov., the causative agent of bacterial haemorrhagic ascites of ayu, Plecoglossus altivelis. Int J Syst Evol Microbiol 50, 83-89.

Oyaizu, H. \& Komagata, K. (1983). Grouping of Pseudomonas species on the basis of cellular fatty acid composition and the quinone system with special reference to the existence of 3-hydroxy fatty acids. J Gen Appl Microbiol 29, 17-40.

Palleroni, N. J. (1992). Introduction to the family Pseudomonadaceae. In The Prokaryotes, 2nd edn, pp. 3071-3085. Edited by A. Balows, H. G. Trüper, M. Dworkin, W. Harder \& K. H. Schleifer. New York: Springer.

Palleroni, N. J. (2005). Genus I. Pseudomonas Migula 1894, $237^{\mathrm{AL}}$. In Bergey's Manual of Systematic Bacteriology, 2nd edn, vol. 2, part B, pp. 323-379. Edited by D. J. Brenner, N. R. Krieg, J. T. Staley \& G. M. Garrity. New York: Springer.

Palleroni, N. J. \& Doudoroff, M. (1972). Some properties and subdivisions of the genus Pseudomonas. Annu Rev Phytopathol 10, 73-100. 
Romanenko, L. A., Uchino, M., Falsen, E., Frolova, G. M., Zhukova, N. V. \& Mikhailov, V. V. (2005). Pseudomonas pachastrellae sp. nov., isolated from a marine sponge. Int J Syst Evol Microbiol 55, 919-924.

Saitou, N. \& Nei, M. (1987). The neighbor-joining method: a new method for reconstructing phylogenetic trees. Mol Biol Evol 4, 406425.

Smibert, R. M. \& Krieg, N. R. (1994). Phenotypic characterisation. In Methods for General and Molecular Bacteriology, pp. 607-654. Edited by P. Gerhardt, R. G. E. Murray, W. A. Woods \& N. R. Krieg. Washington, DC: American Society for Microbiology.
Stackebrandt, E. \& Goebel, B. M. (1994). Taxonomic note: a place for DNA-DNA reassociation and $16 \mathrm{~S}$ rRNA sequence analysis in the present species definition in bacteriology. Int J Syst Bacteriol 44, 846-849.

Thompson, J. D., Gibson, T. J., Plewniak, F., Jeanmougin, F. \& Higgins, D. G. (1997). The CLUSTAL_X windows interface: flexible strategies for multiple sequence alignment aided by quality analysis tools. Nucleic Acids Res 25, 4876-4882.

Xie, C. H. \& Yokota, A. (2003). Phylogenetic analysis of Lampropedia hyalina based on the 16S rRNA gene sequence. J Gen Appl Microbiol 49, 345-349. 